\title{
Addressing an angelomorphic christological myth in Hebrews? ${ }^{1}$
}

\author{
Gert J Steyn \\ Department of New Testament Studies \\ University of Pretoria
}

\begin{abstract}
In this article, the hypothesis of a possible angelomorphic christology, as addressed by the author of Hebrews, is investigated. It is argued that when Jesus was proclaimed as "Son of God", he was probably identified by some of the early believers as an angel. Evidence of similar angelomorphic views held by certain groups in Jewish and early Christian apocalyptic circles at the time of the composition of Hebrews, is listed. The arguments in Hebrews 1 in particular are investigated against this background. It is concluded that, although no explicit polemic against a viewpoint of Jesus as an angel is found in the text, certain angelomorphic elements were applied to him.
\end{abstract}

\section{INTRODUCTION}

The anonymous author of Ad Hebraeos makes the point right at the outset of his work that "the Son" is different from the angels. What prompted him to do so and why does he use seven quotations from Scripture to prove his point that Christ is superior to the angels? Why does he explicitly state that God did not submit the future world to the angels (2:5), but that for a little while made Jesus less than the angels so that he could die for all (2:9)? Why would the author go to such length to point out that Christ is superior to the angels - unless in his opinion his readers had an askewed christology (Stuckenbruck 1995:124; Charles 1990:171-178)? What was the purpose of this comparison between the Son and the angels (Hughes 1979:7)?

\footnotetext{
${ }^{1}$ This article is a revised version of a paper presented at the annual meeting of the New Testament Society of South Africa held at the University of Natal in Pietermaritzburg in April 2003.
} 
The aim of this paper is to explore the hypothesis that the audience of $A d$ Hebraeos might have ventured into the direction of an angelomorphic christology ${ }^{2}$ that was mainly influenced by Jewish apocalyptic angelology. According to this viewpoint, the community probably associated the status of Jesus with that of the angels (or archangels) (see Hannah 1999:137-138; Albl 1999:206-7; Gieschen 1998:294; Stuckenbruck 1995:124-5; Weiss 1991:158-9; Yadin 1965:39,45; Bruce 1985:9; Werner 1953:302,344; Manson 1949:1-17; Tasker 1946:101; Bakker 1933:255). These angelic beings were not only known as "sons of God", but from time to time, when appearing to humans, God also took on an angelic form. The author of Hebrews starts his document by taking a strong stance against a possible askewed christology, arguing that the status of Jesus is higher than and different to that of the angels. Attridge (1989:52) and others (e g Hannah 1999:138; Hengel 1977:131; Michaelis 1942) quite rightly pointed out that the absence of any explicit polemic on angelomorphic christology in Hebrews makes this hypothesis problematic. In this article it will however be argued that the idea of an angelomorphic christology might have existed when Hebrews was being written and that it did not necessarily mean that Jesus was identified as an angel, but that certain angelomorphic elements were applied to him. It can be expected that the quest to define the status of Jesus of Nazareth after his death and resurrection, was still in flux.

In the early 30's Harris already drew attention to this hypothesis when he referred to the Russian form of the Testimonium Flavianum, in which the Russian Josephus declared that he could not call Jesus an angel. For Harris (1931:10) this in turn implied that someone had indeed called him an angel. Thus, both the Russian Josephus and Ad Hebraeos argue against the identification of Christ with an angel. Moreover, the fact that "Cyprian, Justin and a number of other Fathers call Jesus an angel" was taken as "one of the standing titles of Christ" (Bakker 1933:255), in Harris' so-called "Testimony Book" - the hypothetical collection of quotations of which the existence during the $1^{\text {st }}$ century $A D$ is difficult to prove and which is highly controversial today. A similar stance is taken by Albl (1999:201-207). Fact of the matter is that if such an angelomorphic viewpoint did exist, then it belonged to one of the earliest strata of Christian belief. If so, then the author of Hebrews opens his work with an anti-docetic argument.

Before the traces of angelomorphistic views will be followed, it might be useful to briefly refer to angels as mythological beings in antiquity. This chronological starting point is important in order to understand its later influence

${ }^{2}$ See Hannah (1999:2-11) for a history of research on this issue. 
on Jewish apocalypticism when a formal and well developed angelology ${ }^{3}$ is found. It is within this milieu that angelomorphism formed an integral part of first century AD angelology - which, in turn, influenced early christology. It is, however, not the purpose of this paper to focus on how angelomorphism influenced early christology in Hebrews. The focus is rather on (a) gathering evidence from early Jewish and early Christian literature regarding the existence of angelomorphic views that existed by the time when Hebrews was written, (b) on the fact whether the author of Ad Hebraeos might have reacted against an angelomorphic christology, and (c) to identify possible pointers to such an underlying angelomorphic christology in Hebrews 1.

\section{ANGELS AS MYTHOLOGICAL BEINGS IN ANTIQUITY}

The myth of angels could be traced back to Parsee influence in particular. According to Grundmann (1964:74-76), angels' main functions were to serve as mediators between humans and gods, (b) to be messengers, delivering official messages, and (c) to conclude treaties and receive the oath of the contracting party. It is interesting to compare Moses and the Lawgiving in this regard (compare Ac 7:53; GI 3:19 and Heb 2:2 with Ex 33:2 LXX).

In Greek literature the presence of angels is found as far back as in the works of Homer where they served as messengers, stood under special protection of the gods and had sacral roles. At times they were portrayed as messengers of joy (Soph Trach 178; Xen HistGr VI 4,19), as beings who answer questions (Trach 180) and as beings who ask for a reward (Trach 190). These angels were messengers from heaven. Hermes, Persephone, Nemesis (PI Leg IV 717d) and Hecate - linked to Artemis - are all called "angels" (see Grant \& Hazel 1979). In other instances though, some angels are depicted as messengers from the underworld as is the case in Plato (Resp X 619b) and as are found on the Attic curse-tables.

\section{ANGELOLOGY IN JEWISH APOCALYPTICISM}

Apocalypticism was influenced by Iranian (Persian) ideas (Cotterell 1980:141), particularly that of a formal angelology with six (or seven) archangels at the head of the developed hierarchy (Cooke 1964:22-47; Easton 1930:3157-8). One of the existing worldviews at the time was that in the hierarchy before God's throne there were seven archangels. The idea probably originated in Persia and found

\footnotetext{
${ }^{3}$ The term, angelology, is used as an umbrella term for a worldview of angels which consisted of a well developed hierarchy of angelic beings.
} 
its way via Zoroastrianism (after the pattern of the seven Amshaspands, the highest spirits of the religion of Zoroaster (Strong 1996:743; Van Reeth 1994; Tisdall 1930) into Judaism. Traces thereof can still be seen in early Christianity.

A similar doctrine of angels as that of Persia began to develop in early Judaism. This can be seen mainly in the non-canonical writings of Jewish apocalyptic literature from 165 BC-100 AD (Kuhn 1948:217-232). Kuhn describes angelology during Jewish apocalyptic times, depicting a heaven densely populated with beings differing from humans both in rank and function. Their nature and character was seen diversely, so that there was no uniform view of how an angelic being ${ }^{4}$ looked like. Angels were seen as beings possessing both spirits and bodies - with a bodily nature which resembled that of fire. Sometimes men could be transformed into angels. Angels were inferior to God, but superior to man. These angelic beings were seen as immortal, did not have a need for procreation, although intermarriage with human females would sometimes produce giants with perverse morals. Angels went through a probation period, after which they proceeded to a state of righteous character. Their intellectual powers were superhuman - probably due to their nearness to God. A hierarchical pattern, based upon the pattern of the court of Babylon, existed. There is particularly clear evidence of Persian influence on later Jewish thinking with regard to such a hierarchy with two groups of angels: those in close proximity to God and those serving as ministering spirits. At first a list of four "watchers" (1 En 9:1; 1QM 9:14-16; Yadin 1962) is mentioned, which is later followed by a list containing the seven names of the archangels (1 En 20; cf Tob 12:15; Rv 8:2). Amongst the most prominent angels feature the following (see also Gieschen 1998:124-151):

- Uriel, meaning "God is my light", was associated with the stars and therefore was regarded as the leader of the lights of heaven. He was appointed over the world and over Tartarus. The qualities of Uriel coincide with those of the Persian archangel Ameretāt who was identified with immortality and was assigned over the planets.

- $\quad$ Raphael signifies medicina Dei - God's physician (Henry 1996; Jn 5:1). He was seen as the angel of healing and was identified with the angel who stirred the water in Jn 5:1. He was appointed over the spirits of people cf 1 En 9:1; 10:4; 20:3; 40:9-10; Tob 3:16-12:15.) Raphael's qualities agree

\footnotetext{
${ }^{4}$ Angelic beings and angels are used as synonymous terms, unless differently specified.
} 
with those of the Persian angel Haurvatāt who was associated with health (the meaning of her name) and whose domain was the water. She was associated with life after death.

- Raguel, meaning "friend of God", was responsible for the administration of retribution to the world and its celebrities.

- $\quad$ Michael, also an angel of light (1QS 3:22-23; 1QM 13), "the great prince" and guardian angel of the Jews was appointed over the "people" and was the angel of humanity. Other than Gabriel, Michael is the only archangel explicitly mentioned by name in the Bible (cf Dn 10:13-21; 12:1; Jude 9; Rv 12:7; 1 En 9:1; 40:9-10; 1QM 17:6-8; 13:10). Melchizedek (cf 11Q Melch; Ps 82:1-2) was sometimes identified with Michael. The qualities of the Persian angel Khshathra Vairya, who was regarded as the excellent ruler could be compared with those of Michael.

- Saraqâêl, or Sariel, is listed as one of the seven angels and was appointed over those who sinned (cf $1 \mathrm{En} 20$ ). In the lists of four angels he is sometimes replaced by Uriel (1 En 9:1; $1 \mathrm{QM}$ 9:15; cf 1 En 40:6; 54:6; SibOr 2:215 (some manuscripts); BemR 2:10) (Wood 1996:389).

- Gabriel, meaning "God is strong" or "man of God", was the "watcher" over paradise (1 En 20:7), the serpents and the Cherubim. In Dn 8:15-26 and 9:21-27 he appears as a man, interpreting a vision and giving insight to Daniel. Gabriel, who stands in God's presence (Lk 1:19; cf 1 En 9:1; Jub. 2:18; $1 \mathrm{QH} 6: 13$; TgLev $3: 5,7$ ), is the only angel to be mentioned by name in the Gospels (Lk 1:19, 26). Within the imagery of a royal court, it means that he is God's personal servant. 1 Enoch states that Gabriel destroyed the antediluvian giants (1 En 10:9). He will also, together with the other archangels, officiate at the last judgment (1 En 90:21; cf 54:6; SibOr 2:214-219; 1Th 4:16; Rv 8:2) (Wood 1996:389). See also Dn 10:2-9; 1 En $10: 9 ; 40: 9-10$. The qualities ascribed to Gabriel show similarities to those of the Persian angel Asha Vahišta, whose name means "best righteousness". He was the most important male being and was responsible for moral order on earth.

- Remiel had responsibility over "those who rise". 
The names in the lists would sometimes differ. In some of the lists, some of the abovementioned names would be replaced by Yahoel (cf ApAb 10:3-4; 11:1-4). This angel may have been conceived as a personification of the Divine Name or an indwelling of that Name (Yahweh and EI = Yahoel; cf Ex 23:20-21) in an angelic being (Hawthorne 1993:22). Other lists would mention Phanuel, who was responsible for the conversion to hope of those who are to inherit eternal life (1 En 40:9) (Behm 1976:992). It is important to note that all these names end in -el, which points to the close connection with God. These (arch)angels should probably be understood as some form of continuity with the "angel of the Lord" that appeared in the Pentateuch (cf Gn 16:7-14; 22:11-18; Ex 14:19-20). Apocalyptic texts such as Ezk 1:26-28; 8:2-4, where the "glory of the Lord" appears in human-like form, and Dn 7:9-14; 10:2-9, where a heavenly "one like a son of man" and chief angels appear, probably contributed to the tradition (Hawthorne 1993:22). These archangels were seen as leaders of ranks of subordinate spirits. Angels that were thus named, were very few in number. Through the administrative functions ascribed to the angels they became agents through which God performed his will. They brought the prayers of men to the attention of God (particularly through the mediation of the seven special angels), they had guardianship over the righteous dead, cared for the diseased and wounded and were frequently seen as the authors or instructors of the writings of this period of time, revealing to the human authors "everything that is hidden" (Kuhn 1948:218-230; Hawthorne 1993:22).

\section{EVIDENCE OF ANGELOMORPHISTIC VIEWS}

In accordance with Plutarch's viewpoint "that transmutation between the different classes is possible, both from gods downward and from humans upwards (Def 415a-c)", angelomorphic views mainly followed two tracks (Carrell 1997:89) within the angelology of Jewish apocalypticism during Hellenistic times. One track of thinking moved hierarchically downwards, with gods taking on the form of an angel, such as the Israelite God in Dn 12:1 whose presence was represented by Michael, or by that of Yahoel in the Apocalypse of Abraham. One could therefore state that some "angelophanies are reminiscent of theophanies" (Carrell 1997:75; Mach 1992:266). An anthropomorphic view by which angels took on the form of humans and appeared as ordinary men on earth (e g Raphael, Gabriel, Yahoel, etc) occurred most commonly. Casey (1991:78) classifies this group as "purely supernatural beings" which he distinguishes from a second group, that of "abstract figures, such as Wisdom and the Word of God." 
The other track of thinking moved hierarchically upwards, according to which humans too could take on the form of an angel (Carrell 1997:88), such as Melchizedek who, in the Qumran community, is represented by Michael. The ultimate step, that of an angel taking on the form of a god, is however rare. Casey (1991:78) regards this track as a third group of "human beings who are given a status and function beyond the ordinary run of humanity." Hurst argued that "the first two chapters of Hebrews are not concerned primarily with a preexistent figure who lowers himself to become man; they focus rather upon a human being who is raised to an exalted status" (Hurst 1987:152). In this regard, also compare the work of Luck (1963:192-215).

Evidence of existing angelomorphic views held in the Jewish literature leading to, and beyond the time of ad Hebraeos, can be found in the following representative literature.

- The Qumran community identified Melchizedek with the archangel Michael (see Steyn 2002:207-223; Hannah 1999; Casey 1991:80; De Jonge 1991:35; Horton 1976) - thus a human in angelic form.

- The apocryphal Tobit (ca second century BC) (Lamparter 1972:98) reports on how the archangel Raphael appears on earth as a human person (Tob $5: 4-5 ; 9: 1 ; 12: 5,15-16,22)$ - thus an angel in human form.

Therefore he went to seek a man, he found Raphael that was an angel. But he knew not ... (5:4-5). I am Raphael, one of the seven holy angels, which present the prayers of the saints, and which go in and out before the glory of the Holy One. Then they were both troubled, and fell upon their faces, for they feared (12:15-16).

This is probably the earliest reference in Jewish literature to seven archangels (Gore 1932:55). Later, their names would be given in the Book of Enoch. Compare this with Rv 1:4 and 8:2 dealing with the seven angels who are standing before God. Mazdean influence from Zoroastrianism, practised by Cyrus between 538-332 BC, is clearly apparent in Tobit.

- Philo of Alexandria portrayed the Logos of God as an angelomorphic being, "the second God" (ConfLing 146; Som I 238-40; QinGn II 62) (Carrell 1997:91-96; Casey 1991:79; Hurtado 1988:44-46). According to Albl (1999:205), this viewpoint forms part of a so-called "two powers in heaven tradition", but for Hurtado (1988:46), these texts rather reflect the 
personification of divine attributes. Carrell (1997:94) summarises the situation as follows:

When God assumes the likeness of angels he expresses himself as the Logos. The Logos is the manifestation of God and the form of the Logos is the form of an angel. It would appear that the Logos for Philo is not an angel, but the Logos can appear angelomorphically.

- In canonical Daniel, the archangel Michael is closely identified with the presence of God himself (Dn 12:1) (Noll 2000) - thus God in angelic form. Even the name, Michael means "who is like God" (Strong 1996)! He was seen as the first of the chief princes or archangels and was regarded as the patron angel of the Jews $(10: 13,21)$. Elsewhere in Daniel, the angel Gabriel appears to Daniel as a man - thus an angel in human form. His name means "God is strong" or "man of God". He is called "the man Gabriel" and speaks "with a man's voice" as he interprets a vision and gives insight (Dn 8:15-26; 9:21-27) (Hawthorne 1993:20; Wilson 1930:132135). The earliest lists of archangels contain four names (1 En 9:1; $1 \mathrm{QM}$ 9:14-16), while the later ones have seven (1 En 20; cf Tob 12:15; Rv 8:2) (Green 1992:9).

- The pseudepigraphal Apocalypse of Abraham (first to second century AD) (Rubinkiewicz 1983:681-705) is only known in an old Slavonic translation, possibly made via a literal Greek translation of an original Hebrew document (Rubinkiewicz 1983:686-7). The apocalypse describes how the archangel Yahoel is closely identified with the presence of God (Noll 2000) and how he took on a human form.

And while I was still face down on the ground, I heard the voice speaking, "Go, laoel of the same name, through the mediation of my ineffable name, consecrate this man for me and strengthen him against his trembling." The angel he sent to me in the likeness of a man came, and he took me by my right hand and stood me on my feet (9:3-4). I am laoel and I was called so by him who causes those with me on the seventh expanse, on the firmament, to shake, a power through the medium of his ineffable name in me. I am the one who has been charged according to his commandment, to restrain the threats of the living creatures of the cherubim against one another, and I teach those who carry the song through the medium of man's night of the seventh hour (9:8-9). Behold, I am assigned (to be) with you and with the 
generation which is predestined (to be born) from you. And with me Michael blesses you forever. Be bold, go! (9:16-17).

- The pseudepigraphal books known as the Testaments of Abraham, Isaac and Jacob respectively, probably originated from an apocryphal book dating back to the first century AD and which was written in Greek by a Jewish author in Egypt (Sanders 1983:869). The archangel, Michael, resembled Isaac's father Abraham in the second century AD Testament of Isaac (2:1-4) (Russell 1987:80). In the Testament of Jacob, the archangel (probably also Michael) who appears to Jacob, resembles Isaac (2:4) - as is the case in the Testament of Isaac, where the archangel appears to him in the form of his father, Abraham (Russell 1987:80,82). Similarly, in the Prayer of Joseph, "Israel, an angel of God", appears to Joseph in the form of his father Jacob (PrJos Frg A 1,4) (Russell 1987:82).

Evidence of similar viewpoints regarding Jesus is to be found as early as the late first century $A D$ - the same period during which the book of Hebrews is dated. Knight already referred to the fact that this broader kind of angelomorphic christology is present in the early Christian writings:

While a real "angel Christology" (the presentation of Christ quite literally as an angel) was a feature only of marginal groups like the Elkesaites, "angelomorphic christology" of this broader kind is found in many of the New Testament writings and in later literature. It must not be regarded as peripheral; rather, in company with the Jewish Wisdom tradition it allowed some writers to present Jesus as akin and yet subordinate to God.

(Knight 1995:81)

- Jesus' appearance in Rv 19:11-16 as that of an angel-like figure, or angelomorphic Rider, with the name "the Logos of God", is in line with Philo's perception of the Logos as "an angel or, at least, as an angelomorphic being" (Carrell 1997:91).

- The late first century AD Christian interpolation (Russell 1987:114) of chapters 6-11 of the composite pseudepigraphal Ascension of Isaiah (Knight 1995; Müller 1992) (ca AD 90; Hawthorne 1993) is of importance 
here. The interpolation has been dated between the late first and midsecond centuries AD. Bauckham dates it about 70 to 80 AD and Knight, during the Trajanic persecution in the second decade of the second century (Porter 2000). Chapter 10, which describes how Christ descends through the heavens, masking himself in angelic form until he has completed his work on earth (Martin 2000), is of particular relevance. In this adoptionist viewpoint, the heavenly Christ descends and appears as Jesus of Nazareth (Porter 2000). Isaiah's death is recorded as him having been sawn asunder - a motif which is also to be found in Heb 11:37. This pseudepigraphon plays a key role in the argumentation of Werner (1953:344-5).

- Simon, in the Gospel of Thomas 13 (ca end first, beginning second century AD) said of Jesus that he is like a righteous angel (Albl 1999:207).

- Justin Martyr (middle second century AD in Rome) describes the Christ with a list of names, including that of "angel" (Knight 1995:81): ó $\gamma \alpha \dot{\rho} \rho$

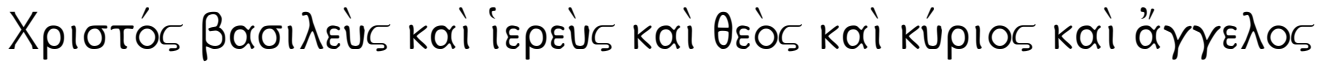

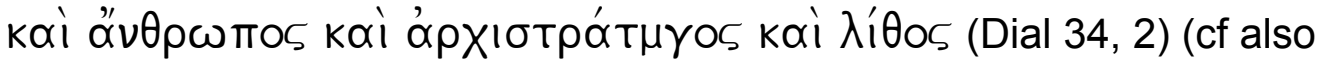
Dial 58,$3 ; 61 ; 126,1.6 ; 128)$. According to Carrell, three different aspects of Christ as an angel are to be found, particularly in Justin's Apologia (i.63): (i) he has the title "angel", derived from Is 9:5 (LXX); (ii) he functions as an angel or messenger; and (iii) he sometimes appeared "in the likeness of angels". "The danger of Jesus being identified with an angel generally, or even with a special angel was not imaginary" (Carrell 1997:99).

- The Pastor of Hermas (ca late first to mid second century AD in Rome) also apocalyptic in nature - applied similar titles to both the Son and the

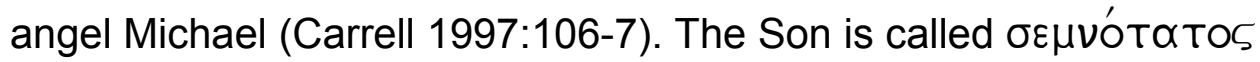

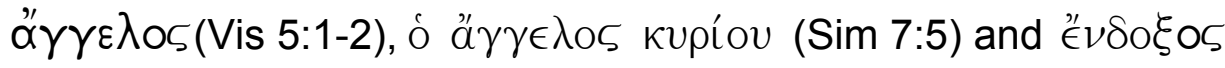

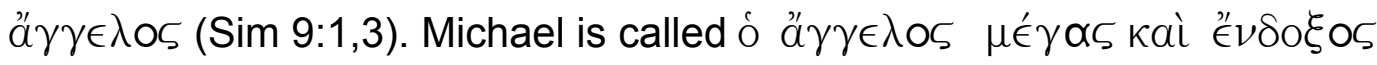
(Sim 8:3) (Albl 1999:207; Bakker 1933:257). See also Man 5:1, 7 and Sim $5: 4.4 ; 7: 1-3$. In Hermas' visions the Son of God is always described as being in the company of six archangels who are God's counselors as well as being guardians of the church (Sim 5.5.3; 9.6.2; 9.12.8). Hermas' 
christology is probably adoptionist (Sim 5.6.) and he identifies a principal angel more strongly with the Spirit than with Christ (Man 11.9) (Martin 2000).

- The Ebionites were Christian Jews who originated in Palestine - possibly as a remnant of the original Jerusalem church. It is probably this same group that other writers knew as the Nazoreans or Nazarenes. Thomson is of the opinion that the "Essenes in all their varieties seem to have come over to Christianity on the fall of the Jewish state and the retreat of the church to Pella. When they joined the believers in their exile the Parsee elements began a ferment in the church and Ebionism was one of the products" (Thomson 1930:893). Eusebius reported that all Ebionites had an aberrant christology (HE 3.27.1.6). Epiphaneus pointed out that "Some saw the Christ as an archangel, while others believed him to be a being created in heaven who had intermittently descended on Adam" (Haer 2.30.1. See also Chrys Pan. 30.16.3-4) (Martin 2000; Carrell 1997:100).

- In a second century Coptic text, the Epistula Apostolorum, it is reported how, during his descent, Christ took on the form of the angel residing in each of the seven heavenly spheres in order to reach the earth without being recognized (Geisler 1996:307). A passage about the Incarnation explicitly states how he appeared in the form of Gabriel:

At that time I appeared in the form of the archangel Gabriel to (the virgin) Mary and spoke with her, and her heart received (me); she believed and laughed; and I, the Word, went into her and became flesh; and I myself was servant for myself, and in the form of the image of an angel; so I will do after I have gone to my Father (Ep Apost 14) (Geisler 1996:307; Carrell 1997:103).

- Cyprian too deals with the subject of Quod idem angelus et deus ("that Christ is at once Angel and God"; Quir 2:5) - a combination also found in Justin (Dial 56, 10; 58, 3.10; 59, 1; 61, 1 \& 128, 4) (Bakker 1933:257).

\section{THE PLACE OF ANGELS IN THE NT}

In the New Testament documents of early Christianity, the angels are shown as being in service of Christ and the believers. (For a discussion on angelomor- 
phism in Luke-Acts, see Fletcher-Louis 1997.) They are present at Jesus' birth, his temptations, his passion (Gethsemane; Lk 22:43) and his resurrection (Mt 28:2-7). The New Testament thus portrays the angels as inferior to Christ. Their focus is on Jesus himself (Green 1992:9). This is important, because it was necessary for him to be portrayed as being superior to them - even superior to the archangels who are in the presence of God at his throne and second in the heavenly hierarchy. The Gospels show marked restraint in their angelology and are not engaging in speculation about angels. The message proclaimed by the writers of the New Testament documents thus states clearly: "The Messiah is not an angelic being" (Grundmann 1964:85).

There are far fewer allusions to angels in the Pauline epistles than there are in the Gospels (Guthrie 1981:138). When Paul refers to the ranks of angels (principalities, powers, etc), then it is only in order to emphasize the complete supremacy of Jesus Christ (Wilson 1930:135). He states in Col 1:16 that the heavenly beings were created through Christ and unto him. In Col 2:18 Paul warns against the "worship of angels" - an allusion which might be interpreted as worship either directed towards angels (objective genitive) or worship led by angels (subjective genitive). The latter would involve "religious practices of abstinence and spiritual discipline aimed at achieving visionary experiences in which one shares in the heavenly worship of angels" (Hawthorne 1993:22). This might have been similar to the kind of worship alluded to in the Angelic Liturgy (4Q400-407 or 4QSirSabb) of Qumran in which humans partake. (The Sabbath Songs of $4 Q$ SirSabb might have had connections with the traditions underlying the reference to the priesthood of Melchizedek in Heb 7:1-3; see Porter 2000). Alternatively, it might have been similar to the esoteric Merkabah visionary tradition attested to in later Jewish texts, in which spiritual adepts penetrate the heavens to the very throne of God and take part in the celestial liturgy ( $3 \mathrm{En}$ ) (Hawthorne 1993:22). Whatever the case may be, the religious setting of this practice is uncertain, but it probably relates to the false teaching at Collosae.

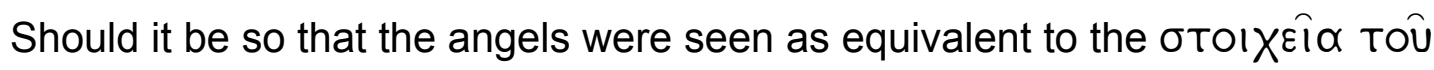

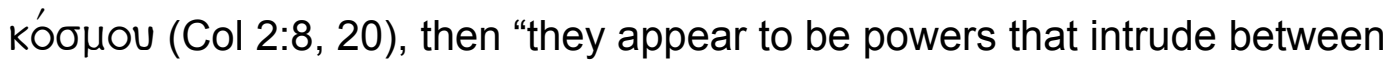
believers and the rightful object of worship, God in Christ". That being the case "Paul would then be warning against a spiritual teaching or practice that dwells on angels to such an extent that they are virtually worshiped - or a teaching that in fact advocates their worship" (Hawthorne 1993:22). Only two instances in the New Testament explicitly refer to archangels: Jude 9 (influenced by contact with apocalyptic literature), refers to the conflict between Michael and the devil over 
the body of Moses. In this instance, not even the archangel anticipated the judgment of God. The other reference is found in 1 Th 4:16 where Paul refers to the archangel's call at the parousia of Christ.

In Hebrews, 1 Peter and Revelation angels receive far more attention which is probably indicative of some progressive belief in angels amongst early Christian communities as time progressed towards the end of the first century AD. Heb 1:14 describes angels as ministering spirits engaged in the service of the saints. Peter also emphasizes the supremacy of Jesus over all angelic beings ( 1 Pt 3:22). It is thus no wonder that a tradition of or refusal of angelic worship existed (Carrell 1997:73) (see Tob 12:16-22; Rv 19:10; 22:8-9; ApZph 6:11-15; Ascenls $7: 18-23 ; 8: 5)$. If the danger of worshiping angels in early Christianity was a reality on the one hand, then the other side of angelic worship was apparently also to be found in the fact that some early Christians displayed blasphemous behaviour. $2 \mathrm{Pt} 10-11$ refers to the blasphemous attitude against the angels as another perspective.

\section{POSSIBLE POINTERS TO ANGELOMORPHIC CHRISTOLOGY IN HEBREWS}

\subsection{Opening argument - surpassing qualities of "the Son"}

Angelology was thus quite well developed by the time Hebrews was written. It is within the context of the above Jewish apocalyptic views on angels that the author wrote his opening argument, as well as the rest of his work. Was it his intention to start in this particular manner in response to an askewed christology by his readers? Does the strong opening argument about the differences between Christ and the angels point to the possibility of some angelomorphic christology? A closer look at the author's line of thought is called for.

Hebrews opens with clear statements in 1:1-4 about the divinity and superiority of the "Son": (a) God spoke to them in these last days through the Son, (b) God created the world through him and made him heir of everything, (c) he radiates the glory of God and is the exact image of the being of God, (d) he maintains everything through his powerful word, (e) he fulfilled the cleansing of sins, (f) he descended into Heaven and sat at the right hand of the Majesty in the high heaven, $(\mathrm{g})$ he is superior to the angels and the name that God gave him is also superior to the name he gave to the angels. By clearly portraying an exalted Christ and by vividly describing his qualities, the levels of suspicion are already raised that the audience had an askewed christology. It is, therefore, not strange 
to note how each of the abovementioned qualities - of which Bruce (1985:3-8) identified seven - surpasses those held by the archangels of Jewish apocalypticism. In this regard compare the following:

- $\quad$ God spoke in these last days through the Son - where the archangels were perceived as angelus interpres, revealing the heavens and God's will to the prophets in the apocalyptic literature and to the authors thereof.

- $\quad$ God created the world through the Son and made him heir of everything in opposition to archangels, such as Uriel, who were seen to rule, or "watch over", the stars and the world.

- The Son radiates the glory of God and is the exact image of the being of God - where the archangels, such as Yahoel, were seen to represent the presence of God on earth to humans.

- $\quad$ The Son maintains everything through his powerful word - where angels, such as Michael, were personally responsible for the wellbeing of the people, and angels such as Gabriel being responsible to keep watch over paradise and the cherubim.

- $\quad$ The Son fulfilled the cleansing of sins - where angels, such as Raguel only oversaw the administration of retribution, and Saraqâêl (Sariel) was only appointed over those who sinned.

- The Son went and sat on the right hand of the Majesty in the high heaven - in opposition to the archangels who rule the heavens below and who are standing as servants in the presence of God's throne

- $\quad$ The Son is superior to the angels just as his name is superior to their names. God proclaims to the Son that he is his Father - in contrast to the archangels who were merely messengers and servants. God's relationship with the angels is formalised only in the title "sons", although he is never associated in paternal relationship with any particular one(s) (Cooke 1964:46).

\subsection{Seven quotations - a further comparison with the angels}

In Heb 1:5-14 follows a comprehensive exposition of reasons why the Son is different to the angels and those reasons are substantiated with seven explicit 
quotations from the Scriptures placed in the mouth of God himself. Five of these are from the Psalms, one from $1 \mathrm{Sm}$ and one from the Song of Moses (Dt 32/Ode 2). The argument runs as follows:

\begin{tabular}{|l|l|l|}
\hline God called him his Son, and himself his Father & Heb 1:5a & Ps 2:7 \\
\hline God called himself his Father and him his Son & Heb 1:5b & 2 Sm 7:14 \\
\hline $\begin{array}{l}\text { When God brought this first born into the world, he said that } \\
\text { all the angels must worship him }\end{array}$ & Heb 1:6 & $\begin{array}{l}\text { Dt 32:43 } \\
\text { Ode 2 }\end{array}$ \\
\hline $\begin{array}{l}\text { God said that he makes his angels storm winds and his } \\
\text { servants flames of fire }\end{array}$ & Heb 1:7 & Ps 104:4 \\
\hline $\begin{array}{l}\text { However, he said of the Son that his throne - "O God" - } \\
\text { stands forever. Because he is just and stands for justice, } \\
\text { God anointed him as king. }\end{array}$ & $\begin{array}{l}\text { Heb 1:8- } \\
9\end{array}$ & Ps 45:6-7 \\
\hline $\begin{array}{l}\text { God acknowledges that this "Lord" made heaven and earth. } \\
\text { This will pass away, but he is eternal an there is "no end to } \\
\text { his years". }\end{array}$ & $\begin{array}{l}\text { Heb } 1: 10-12 \\
\text { God did not say of any angel that he should sit at God's }\end{array}$ & Ps 102:25- \\
\hline $\begin{array}{l}\text { Gob 1:13 } \\
\text { right hand and that he will submit his enemies to him. }\end{array}$ & Ps 110:1 \\
\hline
\end{tabular}

Compare these elements with those found in the hymn in $1 \mathrm{Tm} 3: 16$. Four of the six elements mentioned there are similar to those found in Heb 1:5-14. It is clear that the relationship between the Son and God is different to that between God and the angels. It is perhaps not incidental that seven quotations are listed with seven qualities distinguishing the Son from the angels. The number of seven could very well point to the apocalyptic background of this passage. The fact that these qualities might have been compared with those of the archangels, should be added to this possibility. By listing them, the author's audience would recognise the qualities of the archangels and would, by way of comparison, see the differences between Christ and each of these angels.

It is important to bear in mind that different lists of archangels existed.

There was however a core, consisting of the same names and qualities or functions, but the remaining names were sometimes interchanged with others. Any attempt to find an exact match of the qualities of these archangels with those listed in the seven quotations above, would probably encounter difficulties in finding such an exact overlap. Not only was there a transition from the Persian beings to those of Jewish apocalypticism, but these angels were adapted in different geographical areas to suit their own contexts. However, the broader picture leaves no doubt that the qualities ascribed to the Son clearly distinguish him from the qualities ascribed to those angels. 
An attempt at a comparison between the above quotations and the Persian beings, is as follows:

\begin{tabular}{|l|l|l|l|}
\hline Quotation & Qualities in Hebr & Qualities of angels & Name of Being \\
\hline $\begin{array}{l}\text { Ps 2:7 } \\
\text { 2 Sm 7:14 }\end{array}$ & $\begin{array}{l}\text { Son Father generates } \\
\text { Father - Son }\end{array}$ & $\begin{array}{l}\text { Daughter of Mazda; } \\
\text { bounteous piety }\end{array}$ & Speñta Armaiti \\
\hline $\begin{array}{l}\text { Dt 32 / Ode 2 } \\
\text { Ps 104:4 }\end{array}$ & $\begin{array}{l}\text { Angels must worship } \\
\text { Angels = winds, flames }\end{array}$ & Messenger, obedience & Sraosha \\
\hline Ps 45:6-7 & Eternal throne & Excellent ruler & $\begin{array}{l}\text { Khshathra } \\
\text { Vairya }\end{array}$ \\
\hline Ps 45:6-7 & Justice/righteousness & Best righteousness & Asha Vahišta \\
\hline Ps 102:25-27 & Creator: heaven, earth & Immortality, planets & Ameretāt \\
\hline Ps 102:25-27 & Eternal existence & Health, water & Haurvatāt \\
\hline Ps 110:1 & $\begin{array}{l}\text { Exaltation \& rule, } \\
\text { submission of enemies }\end{array}$ & $\begin{array}{l}\text { Good mind, wisdom. } \\
\text { Mazda's good thought. }\end{array}$ & Vōhu manō \\
\hline
\end{tabular}

This second set of qualities (the first being those listed in Heb 1:1-4) is both a continuation and an exposition of those already listed. These are substantiated by explicit quotations from Scripture and are presented as God's own words.

\subsection{Argumento e silentio?}

Seven underlying (mainly christological) "titles" are used in the quotations. The list coincides with that in Justin. However, only six of these titles are applied to Christ. The remaining one, "angel", is not applied to Christ. Using the same list as above, but applied to these underlying titles, the following surfaces:

\begin{tabular}{|c|c|c|}
\hline Quotation & Qualities in Hebr & \\
\hline $\begin{array}{l}\text { Ps } 2: 7 \\
2 \text { Sm } 7: 14\end{array}$ & $\begin{array}{l}\text { Son - Father generates } \\
\text { Father -- Son }\end{array}$ & viós \\
\hline $\begin{array}{l}\text { Dt } 32 \text { / Ode } 2 \\
\text { Ps } 104: 4\end{array}$ & $\begin{array}{l}\text { Angels must worship } \\
\text { Angels = winds, flames }\end{array}$ & $\alpha^{\prime \prime} \gamma \gamma \varepsilon \lambda \circ \sigma$ \\
\hline Ps 45:6-7 & Eternal throne & 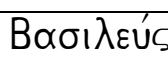 \\
\hline Ps 45:6-7 & Justice/righteousness & 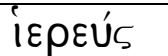 \\
\hline Ps 102:25-27 & Creator: heaven, earth & 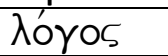 \\
\hline Ps 102:25-27 & Eternal existence & \\
\hline Ps 110:1 & $\begin{array}{l}\text { Exaltation \& rule, submission } \\
\text { of enemies }\end{array}$ & $\begin{array}{l}\text { EEós } \\
\text { Kup'́os }\end{array}$ \\
\hline
\end{tabular}

\subsection{Sons of God" and "angels"}

Casey (1991:79) assumed that "Son of God' was already in use by occasional outsiders during the historical ministry to indicate an exceptional human being." The phrase "sons of God" was known as a synonym for angels. The LXX translators used the term $\alpha^{\prime} \gamma \gamma \varepsilon \lambda$ os as translation equivalent in a number of places as translation for the Hebrew phrase "son(s) of God" (Gn 6:2.4; Job 1:6; 
$2: 1 ; 38: 7 ;$ Ps $29: 1 ; 89: 6)$. Yadin strongly urged that angels were regarded as God's sons and dominated eschatology at Qumran. The phrase "Sons of God" is used in the sense of denoting to angels in Dt 32:43 (4QDt ${ }^{\mathrm{a}}$ ) (Archer \& Chirichigno 1983:49-50). The author of Hebrews explicitly follows this direction and has the reading ${ }^{\prime} \gamma \gamma \varepsilon \lambda$ ol $\theta \varepsilon \circ \hat{O}$ for the quotation in Heb 1:6 - similar to that of Ode 2:43 and not the reading "sons of God" (Karrer 2002:134-6; Steyn 2000:263-272; Mach 1992:75-79; Hurst 1987:158).

The LXX translators even used the term ${ }^{\prime \prime} \gamma \gamma \varepsilon \lambda$ ol $\zeta$ as translation equivalent for $\mu$ hl a (Ps 8:5; 97:7; 138:1; see Schenker 2001; Mach 1992:74-75). Furthermore, the quotation from Ps 8 in Heb 2:7, 9 via the LXX reads ${ }^{\alpha} \gamma \gamma \gamma^{\prime} \lambda$ ous in lieu of $\mu$ yl a (Steyn 2003).

For Berger, Christ as the Son of God in a natural sense stood in close affinity to the angels "denn er gehört wie sie zur 'familia dei', zum allernächsten Hofstaat Gottes". Heb 1:4-14 then states that the Son of God is above the angels and those who are resurrected are also sons of God (Lk 20:36; Rm 1:4) (1995:62). But according to Spicq, only Christ is called "Son" in Heb 1, 5 - the angels, on the other hand, are not known as "sons of God" neither in Hebrews, nor at Qumran. They are known as "Himmelsöhne" (1QS 4:22; 11:8; $1 \mathrm{QH}$ 3:22; 2:10) in Qumran. Spicq uses this as part of his argumentation that Heb 1 was polemically anti-Qumran directed, where Christ is set above the angels (Spicq 1959:377). Braun reacts to this argument as follows:

Falls der Hebräerbrief gegen eine qumranische Form der Engellehre polemisierte, müßte man zum mindesten erwarten, er werde die Singularform "Sohn" als höherwertig gegen eine Pluralität von "Söhnen" absetzen. Statt dessen sieht der Hebräerbrief die Überlegenheit Christi durch den Sohnesnamen nachwiesen, ohne den Singular gegen einen Plural zu stellen. Der Hebräerbrief setzt den Sohnesnamen also in keiner Form als Engelbezeichnung bei den Gegnern voraus.

(Braun 1966:242)

\section{CONCLUSIVE REMARKS}

- $\quad$ Although the importance for early christology of angelomorphic traditions is advocated by very few scholars (Gieschen 1998:3), it is no indication of the role it played. One of the traces of the Jewish background of early christology is to be found precisely in angelomorphism, particularly within 
the sphere of Jewish apocalypticism. (For further discussion on the topic, see Casey 1991; Fossum 1987; Dunn 1980; McDonald 1975; Riesenfeld 1964; Barbel 1964; Michaelis 1942.) According to Gieschen, angelomorphic traditions "had a significant impact on the early expressions of Christology to the extent that evidence of an Angelomorphic Christology is discernible in several documents dated between 50 and $150 \mathrm{CE}$ " (Gieschen 1998:6). The role of angelic speculation in the theological world of Second Temple Judaism and early Christianity should therefore not be underestimated (Albl 1999:206).

- $\quad$ Angelology in the period of early Judaism and early Christianity does not belong to the Sadducean Judaism (cf Ac 28:8) neither is it very close to Pharasaic Judaism (cf the restrained angelology in writings such as Tobit, Wisdom of Solomon, $1 \mathrm{Mac}$ and $2 \mathrm{Mac}$ ). Kohler is of the opinion that the angelology of the apocalypses goes back to Essene speculation (Charles 1990:172; Kuhn 1948:231). Although it remains inconclusive whether the author of Hebrews had possible "Essene-type Christians or exQumranians" (Charles 1990:173) in mind, it can be assumed that it had converts of a similar profile as its readers. Parallels in the theology of the Dead Sea Scrolls and a possible form of "himmlische Kultus" (Dibelius 1956:160-176) in Hebrews also point in this direction.

- There is little doubt, though, that the readers of Hebrews were familiar with angels and transformation into angelomorphic beings. Angelology is one of the many themes, or motifs, to be found in Hebrews. References particularly occur at the beginning (Heb 1:4-14; 2:2-16) and at the end of the book (13:2). Some communities, amongst them even early Christian communities, went further than having mere knowledge about angels, they worshiped them. Traces of this can possibly be found in Col 2:18 and Rv 22:8. If the author of Hebrews was not specifically correcting a myth about Jesus being identified with an angel, then at least his readers had "an inordinate revering of angels and subsequent depreciation of the person and ministry of Jesus" (Charles 1990:178). In this connection Stuckenbruck rightly argues that it is actually "impossible to decide between an argument against a veneration of angels and an 'angel Christology"' (1995:137). 
- Hebrews 1 represents an effort to clearly distinguish Christ from the angels (Albl 1999:207). A clear distinction between Christ and the angels does not preclude the presence of angelomorphic christology either. In this author's opinion, Gieschen is on the right track in his assessment that ideas and terminology in Heb 1 "have been influenced by, and adopted from, angelomorphic traditions." Five such elements identified by Gieschen are the Son's role in creation, possession of the Divine Name, designation as "Firstborn", description as "Radiance of the Glory" and his enthronement. No clear polemic against these angelomorphic traditions is found, but the author embraced angelomorphic christology as support for the superiority of Christ (Gieschen 1998:294-303, 314).

- It seems as if the matter of Jesus being identified as an angel during the first centuries, can largely be classified under the category of "angelomorphic Christology", i e Jesus was not actually understood as being an angel, but rather identified with the "angel of the Lord" (Bakker 1933:263). He was therefore being entitled "angel". He was likened to an angel in terms of his function and was temporarily taking up the form of an angel (Carrell 1997:110). The strong appeal to scriptural traditions and motifs in Heb 1-2 and the clear distinction between Christ and the angels, in the words of Stuckenbruck, "at the very least suggest a polemic against a Zeitgeist in which the fluid ideas about angels and preeminent heavenly figures, however metaphorically conceived, were perceived as a threat to a belief in a surpassing exaltation of Christ" (1995:39). The fact, then, that "the author of Hebrews 'does go on a bit' in stressing Christ's superiority to angels" means that the danger of blurring the distinction between Christ and the angels was in the air (Hannah 1999:138).

\section{Works consulted}

Albl, M C 1999. And Scripture cannot be broken: The form and function of the early christian testimonia collections. Leiden: Brill.

Archer, G L \& Chirichigno, G 1983. Old Testament quotations in the New Testament. Chicago, IL: Moody Press.

Attridge, H W 1989. The epistle to the Hebrews. Philadelphia, PA: Fortress Press. (Hermeneia.)

Bakker, A 1933. Christ an Angel? ZNW 32, 255-265.

Barbel, J 1964. Christos Angelos: Die Anschauung von Christus als Bote und Engel in der gelehrten und volkstümlichen Literatur des christlichen Altertums. Bonn: Hanstein. 


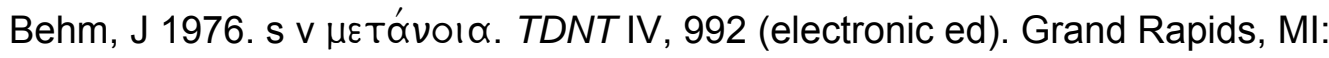
Eerdmans.

Berger, K 1995. Theologiegeschichte des Urchristentums 2. Aufl. Tübingen: Francke Verlag.

Braun, H 1966. Qumran und das Neue Testament, I. Tübingen: Mohr.

Bruce, F F 1985. The epistle to the Hebrews. Grand Rapids, MI: Eerdmans. (NICNT.)

Carrell, P R 1997. Jesus and the angels: Angelology and the christology of the apocalypse of John. Cambridge: Cambridge University Press. (MSSNTS 95.)

Casey, P M 1991. From Jewish prophet to gentile God: The origins and development of New Testament christology. Louisville, KY: Westminster John Knox.

Charles, J D 1990. The angels, sonship and birthright in the letter to the Hebrews. JETS 33(2), 171-178.

Cooke, G 1964. The sons of (the) god(s). ZAW 76, 22-47.

Cotterell, A (ed) 1980. The encyclopedia of ancient civilizations. London: Rainbird Publishing Group.

De Jonge, M 1991. The role of intermediaries in God's final intervention in the future according to the Qumran Scrolls, in Jewish eschatology, early Christian christology and the testaments of the twelve patriarchs: Collected essays of Marinus de Jonge, 28-47. Leiden: Brill. (SNT 63.)

Dibelius, M 1956. Der himmlische Kultus nach dem Hebräerbrief, in Bornkamm, G (hrsg), Botschaft und Geschichte II: Zum Urchristentum und zur hellenistischen Religionsgeschichte. Gesammelte Aufsätze von Martin Dibelius, 160-176. Tübingen: Mohr.

Dunn, J 1980. Christology in the making: An inquiry into the origins of the doctrine of the incarnation. London: SCM Press.

Easton, B S 1930. s v Zoroastrianism, 3157-8. Chicago, IL: Howard-Severance Company. (ISBE V.)

Fletcher-Louis, C H T 1997. Luke-Acts: Angels, christology and soteriology. Tübingen: Mohr. (WUNT 94.)

Fossum, J 1987. Kyrios Jesus as the angel of the Lord in Jude 5-7. NTS 33, 236-237. Geisler, N L 1996. A general Introduction to the Bible. Chicago, IL: Moody Press.

Gieschen, C A 1998. Angelomorphic christology: Antecedents and early evidence. Leiden: Brill. (AGAJU 42.)

Gore, C, Goudge, H L \& Guillaume, A (eds) 1932. A new commentary on holy scripture including the apocrypha. New York, NY: The Macmillan Co.

Grant, M \& Hazel, J 1979. Gods and mortals in classical mythology: A dictionary. New York, NY: Dorset Press.

Green, J B 1992. Dictionary of Jesus and the gospels (electronic ed). Downers Grove, IL: InterVarsity Press.

Harris, J R 1931. Josephus and his testimony. Cambridge: Heffer \& Sons.

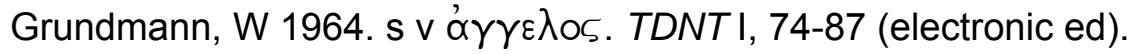

Guthrie, D 1981. New Testament theology. Leicester: Inter-Varsity Press.

Hannah, D L 1999. Michael and Christ: Michael traditions and angel christology in early christianity. Tübingen: Mohr. (WUNT 109.) 
Hawthorne, G F 1993. Dictionary of Paul and his letters (electronic ed). Downers Grove, IL: InterVarsity Press.

Hengel, M 1977. Der Sohn Gottes: Die Entstehung der Christologie und die jüdischhellenistische Religionsgeschichte. Tübingen: Mohr.

Henry, M 1996. Matthew Henry's commentary on the whole Bible: Complete and unabridged in one volume (electronic ed). Peabody, MA: Hendrickson.

Horton, F L 1976. The Melchizedek tradition: A critical examination of the sources to the fifth century $A D$ and in the epistle to the Hebrews. Cambridge: Cambridge University Press. (SNTSMS 30.)

Hughes, G 1979. Hebrews and hermeneutics. The epistle to the Hebrews as a New Testament example of Biblical interpretation. Cambridge: Cambridge University Press. (SNTS MS 36.)

Hurst, L D 1987. The christology of Hebrews 1 \& 2, in Hurst, L D \& Wright, N T (eds), The glory of Christ in the New Testament, 151-164. Oxford: Clarendon Press.

Hurtado, L W 1988. One God, One Lord: Early Christian devotion and ancient Jewish monotheism. Minneapolis, MN: Fortress Press.

Karrer, M 2002. Der Brief an die Hebräer: Kapitel 1, 1-5, 10. Gütersloh: Gütersloher Verlagshaus. (ÖTKNT 20/1.)

Knight, J M 1995. The ascension of Isaiah. Sheffield: Sheffield Academic Press.

Kuhn, H B 1948. The angelology of the non-canonical Jewish apocalypses. JBL 67, 217-232.

Lamparter, H 1972. Die Apokryphen, II. Stuttgart: Calwer Verlag. (Die Botschaft des Alten Testaments 25, II.)

Luck, U 1963. Himmlisches und irdisches Geschehen im Hebräerbrief. NT 6, 192-215.

Mach, M 1992. Entwicklungsstadien des jüdischen Engelglaubens in vorrabbinischer Zeit. Tübingen: Mohr. (TSAJ 34.)

Manson, TW 1949. The problem of the epistle to the Hebrews. BJRL 32, 1-17.

Martin, R P 2000. Dictionary of the later New Testament and its developments. (electronic ed). Downers Grove, IL: InterVarsity Press.

McDonald, W 1975. Christology and the "Angel of the Lord", in Hawthorne, G (ed), Current issues in biblical and patristic interpretation: Studies in honor of Merrill C Tenney presented by his former students, 324-335. Grand Rapids, MI: Eerdmans.

Michaelis, W 1942. Zur Engelchristologie im Urchristentum: Abbau der Konstruktion Martin Werners. Basel: Heinrich Majer. (GBTh 1.)

Müller, C D G 1992. The ascension of Isaiah, 603-620, in Hennecke, E \& Schneemelcher, W (eds), New Testament Apocrypha II. Cambridge: Cambridge University Press.

Noll, S F 2000. s v Angels, Martin, R P (ed), Dictionary of the later New Testament and its developments (electronic ed). Downers Grove, III: InterVarsity Press.

Porter, S E 2000. Dictionary of New Testament background: A compendium of contemporary biblical scholarship. (electronic ed). Downers Grove, IL: InterVarsity Press. 
Riesenfeld, H 1964. The mythological background of New Testament christology, in Davies, W D \& Daube, D (eds), The background of the New Testament and its eschatology: In honour of C H Dodd, 81-95. Cambridge: Cambridge University Press.

Rubinkiewicz, R 1983. Apocalypse of Abraham, in Charlesworth, J H (ed), The Old Testament Pseudepigrapha I, 681-705. New York, NY: Doubleday.

Russell, D S 1987. The Old Testament Pseudepigrapha. Philadelphia, PA: Fortress Press.

Sanders, E P 1983. Testaments of the Three Patriarchs, in Charlesworth, J H (ed), The Old Testament Pseudepigrapha I, 869-902. New York, NY: Doubleday.

Schenker, A 2001. Götter und Engel im Septuaginta-Psalter: Text- und religionsgeschichtliche Ergebnisse aus drei textkritischen Untersuchungen, in Zenger, E (Hrsg), Der Septuaginta-Psalter: Sprachliche und Theologische Aspekte, 185-195. Freiburg: Herder.

Spicq, C 1959. L'épître aux Hébreux, Apollos, Jean-Baptiste, les Hellénistes et Qumran. Revue de Qumran 1, 365-390.

Steyn, G J 2000. A quest for the Vorlage of the song of Moses (Dt 32) quotations in Hebrews. Neotestamentica 34(2), 263-272.

Steyn, G J 2002. The Vorlage of the Melchizedek phrases in Heb 7:1-4. Acta Patristica et Byzantina 13, 207-223.

Steyn, G J 2003. Some observations about the Vorlage of Ps 8, 5-7 in Heb 2, 6-8. Verbum et Ecclesia 24(2) (forthcoming).

Strong, J 1996. Enhanced Strong's Lexicon. Ontario: Woodside Bible Fellowship.

Stuckenbruck, L T 1995. Angel veneration and christology. Tübingen: Mohr. (WUNT 70.) Tasker, R V G 1946. The Old Testament in the New Testament. London: SCM Press. Thomson, J E H 1930. s v Ebionism. ISBE II, 890-894. Chicago, IL: Howard-Severance Company.

Tisdall, W ST C 1930. s v Persion religion (ancient), ISBE IV, 2331-2335. Chicago, IL: Howard-Severance Company.

Van Reeth, A 1994. Ensiklopedie van die mitologie. Vlaeberg: Vlaeberg Uitgewers.

Weiss, H-J 1991. Der Brief an die Hebräer. Göttingen: Vandenhoeck \& Ruprecht. (KEK 13.)

Werner, M 1953. Die Entstehung des christlichen Dogmas. Bern: Haupt.

Wilson, J M 1930. s v Angel, 132-135. Chicago, IL: Howard-Severance Company. (ISBE I.)

Wood, D R W 1996. New Bible Dictionary (electronic ed). Downers Grove, IL: InterVarsity Press.

Yadin, Y 1962. The scroll of the war of the sons of light against the sons of darkness, 229-242. Oxford: University Press.

Yadin, Y 1965. The dead sea scrolls and the epistle to the Hebrews. Scripta Hierosolymitana 4, 39-45. 